\title{
Vendor Information Documentation
}

National Cancer Institute

\section{Source}

National Cancer Institute. Vendor Information Documentation. NCI Thesaurus. Code C115743.

Records containing information pertaining to a specific vendor. 